\title{
Mechanism of liver-selective thyromimetic activity of SK\&F L-94901: evidence for the presence of a cell-type-specific nuclear iodothyronine transport process
}

\author{
K Ichikawa, T Miyamoto, T Kakizawa, S Suzuki, A Kaneko, \\ J Mori, M Hara, M Kumagai, T Takeda and K Hashizume \\ Department of Aging Medicine and Geriatrics, Shinshu University School of Medicine, Asahi 3-1-1, Matsumoto-City 390-8621 Japan \\ (Requests for offprints should be addressed to K Ichikawa; Email: kazuichi@hsp.md.shinshu-u.ac.jp)
}

\begin{abstract}
The thyromimetic compound SK\&F L-94901 shows more potent thyromimetic activity in the liver than in the pituitary gland or heart when administered to rats. The mechanisms of liver-selectivity of SK\&F L-94901 were examined using cultured rat hepatoma cells (dRLH-84) and rat pituitary tumor cells (GH3), both of which showed saturable cellular uptake of tri-iodothyronine $\left(\mathrm{T}_{3}\right)$. When isolated nuclei with partial disruption of the outer nuclear membrane were used, SK\&F L-94901 competed for $\left[{ }^{125} \mathrm{I}\right] \mathrm{T}_{3}$ binding to nuclear receptors almost equally in dRLH-84 and GH3 cells. SK\&F L-94901 also did not discriminate thyroid hormone receptors (TR) $\alpha 1$ and $\beta 1$ in terms of binding affinity and activation of the thyroid
\end{abstract}

hormone responsive element. In intact cells, however, SK\&F L-94901 was a more potent inhibitor of nuclear $\left[{ }^{125} \mathrm{I}\right] \mathrm{T}_{3}$ binding in dRLH-84 cells than in GH3 cells at an early phase of the nuclear uptake process and after binding equilibrium. These data suggest that SK\&F L-94901 is more effectively transported to nuclear TRs in hepatic cells than in pituitary cells and therefore shows liverselective thyromimetic activity. In conclusion, SK\&F L-94901 discriminates hepatic cells and pituitary cells at the nuclear transport process. The cellular transporters responsible for this discrimination were not evident.

Journal of Endocrinology (2000) 165, 391-397

\section{Introduction}

Thyroid hormones exert biological effects mainly through nuclear receptors by regulating the expression of hormone-responsive genes (Oppenheimer et al. 1987). However, present understanding of the mechanisms of hormone action is not sufficient to explain the diversity of thyroid hormone action in various tissues and at various levels of development. Studies have revealed that, even in the nucleus, models of hormone action are not simple but involve interaction of multiple forms of receptors with multiple nuclear proteins, and that thyroid-hormone responsive elements (TREs) located on the hormoneresponsive genes are diverse (Baniahmad et al. 1993, Lazar 1993, Lopez et al. 1993, Miyamoto et al. 1993, 1997, Lee et al. 1995). Besides these nuclear events, many events occur before the hormones reach nuclear receptors. The hormones enter the cells through the plasma membrane, are distributed to various cellular compartments, are metabolized to inactive or active compounds and finally enter nuclei through the nuclear membrane. Cellular transport of the hormones could be by passive diffusion (Lein \& Dowben 1961, Weisiger et al. 1992) but there is now evidence to support an energy-dependent carrier- mediated process for the cellular uptake of thyroid hormones (Eckel et al. 1979, Krenning et al. 1989). Nuclear transfer of the hormones may also involve active processes (Oppenheimer \& Schwartz 1985) and may be regulated independently (Ichikawa et al. 1992). Cellular transport of thyroid hormones shows analog specificity and stereospecificity (Oppenheimer \& Schwartz 1985); furthermore, the cellular transport of different thyronine analogs involves different mechanisms and these diversities vary from organ to organ (Everts et al. 1996, Nagasawa et al. 1995). It is therefore possible that extranuclear events contribute to the diversity of thyroid hormone action in various tissues and at various levels of development.

SK\&F L-94901 is a thyromimetic compound that exerts thyromimetic activity on the liver but not on the heart and pituitry gland when administered to rats in vivo (Underwood et al. 1986). We have examined how this compound exerts liver-selective thyromimetic activity and found that it discriminates different cell types at the level of the nuclear transport process, either by favoring nuclear uptake in the liver or by impairing nuclear uptake in the pituitary. This further verifies the presence of distinct mechanisms of transport of thyroid hormones into the nucleus. 


\section{Materials and Methods}

Cultured rat hepatoma dRLH-84 cells (Hashizume et al. 1991, Tanaka et al. 1989), were provided by the Japanese Cancer Research Resources Bank (Tokyo). A continuous line of cultured cells derived from rat pituitary tumor GH3 cells (Tashjian et al. 1968) were obtained from the American Type Culture Collection (Rockville, MD, USA). Culture media, penicillin, streptomycin, trypsin and EDTA were from Flow Laboratories (McLean, VA, USA); fetal calf serum (FCS) was from Filtron (Brooklyn, Australia). $\left[{ }^{125} \mathrm{I}\right] 3,5,3^{\prime}$-tri-iodo-L-thyronine $\left(\mathrm{L}-\mathrm{T}_{3}\right)(2800-$ $3400 \mu \mathrm{Ci} / \mu \mathrm{g})$ and $\left[{ }^{125} \mathrm{I}\right]$ thyroxine $\left(\mathrm{L}-\mathrm{T}_{4}\right) \quad(1080-$ $1320 \mu \mathrm{Ci} / \mu \mathrm{g}$ ) were from New England Nuclear (Boston, MA, USA) and $\mathrm{L}-\mathrm{T}_{3}$ and $\mathrm{L}-\mathrm{T}_{4}$ were from Sigma Chemical Co. (St Louis, MO, USA).

\section{Binding of thyronine analogs to isolated nuclei}

The cells were harvested by trypsinization. Isolation of nuclei and nuclear $\left[{ }^{125} \mathrm{I}\right] \mathrm{T}_{3}$ binding assays were carried out as described previously (Ichikawa et al. 1992). Phasecontrast microscopy revealed that the nuclear preparation was free of intact cells and had little cytoplasmic contamination and that integrity of the nuclei was well preserved; however, nuclei isolated in this way exhibited a separation of the outer nuclear membrane from the inner membrane on electron microscopy (Ichikawa et al. 1986). To determine the binding of SK\&F L-94901 to the nuclear receptor, isolated nuclei were incubated with $14.4 \mathrm{pM}$ $\left[{ }^{125} \mathrm{I}\right] \mathrm{T}_{3}$ with various concentrations of SK\&F L-94901, $\mathrm{T}_{3}$ or $\mathrm{T}_{4}$. The amount of SK\&F L-94901 required to prevent $\left[{ }^{125} \mathrm{I}_{3} \mathrm{~T}_{3}\right.$ binding was used to estimate the potency of binding of SK\&F L-94901 to nuclear receptors.

Preparation of soluble thyroid hormone receptor (TR) subtypes $\alpha 1$ and $\beta 1$ using Sf9 insect cell expression

The methods used for construction of the human TR $\alpha 1$ and $\beta 1$ transfer vectors, expression of recombinant TRs in Sf9 insect cells, extraction of recombinant proteins, and characterization of expressed receptors have been described previously (Miyamoto et al. 1997). In brief, the entire coding region of human TR $\alpha 1$ cDNA in pMe21 (Nakai et al. 1988) was PCR-amplified and inserted into the BamH1-HindIII site of pBlueBacHisC (Invitrogen, San Diego, CA, USA). This plasmid was designed to produce $6 \times($ His $)$ fused human TR $\alpha 1$. For TR $\beta 1$, a $1.5 \mathrm{~kb}$ BamHI-EcoRI fragment containing human TR $\beta 1$ was inserted into the BglII-EcoRI cleaved baculovirus transfer vector $\mathrm{pVL} 1392$ (Invitrogen). This transfer vector was expected to produce a full-length non-fused human TR $\beta 1$ protein. General baculovirus procedures (insect cell culture, transfection, isolation and purification of recombinant plaques, infection) were performed as described previously (Summers \& Smith 1988). Sf9 cells were cultured in Grace's insect medium containing 10\% FCS at $27^{\circ} \mathrm{C}$, as attached cells in flasks. Antibiotics $(50 \mathrm{mg} / \mathrm{ml}$ gentamicin and $25 \mathrm{mg} / \mathrm{ml}$ fungizone) were used during protein expression and production of viral stocks. For the extraction of recombinant proteins, cells infected with recombinant baculovirus were harvested $72 \mathrm{~h}$ after infection by centrifugation at $800 \times \mathbf{g}$ for $10 \mathrm{~min}$ and washed twice with PBS. The washed cell pellet was resuspended in $20 \mathrm{mM}$ Tris $-\mathrm{HCl} \mathrm{pH} 7 \cdot 5$, containing $400 \mathrm{mM} \mathrm{NaCl}$, $1 \mathrm{mM}$ EDTA, $1 \mathrm{mM}$ dithiothreitol (DTT), $1 \mathrm{mM}$ phenylmethylsulfonyl fluoride and 20\% glycerol, and disrupted by three freeze-thaw cycles. Supernatants containing recombinant receptors were used for further experiments.

\section{Activation of TR subtypes in COS1 cells}

For determinations of the potency of compounds to activate TR $\alpha 1$ or $\beta 1$, COS1 cells were co-transfected with pCDM designed to express TR $\alpha 1$ or $\beta 1$ (Miyamoto et al. 1997) and PAL-TK-luciferase reporter plasmid containing two copies of the palindromic TRE sequence, 5'-GGATCCAGGTCATGACCTGGATCC-3 (Miyamoto et al. 1997). A calcium phosphate precipitation technique was used for the transfection. Twenty hours after transfection, transfected cells were incubated with various compounds for $24 \mathrm{~h}$ in culture media containing $10 \%$ FCS and cells were harvested for the determination of luciferase activity. Details of the methods of plasmid construction, transfection, cell culture and luciferase assay have been described elsewhere (Miyamoto et al. 1997).

\section{Thyroid hormone uptake study}

The cellular and nuclear thyroid hormone uptake study was performed as described previously (Ichikawa et al. 1992, Nagasawa et al. 1995). In brief, cells grown in $60 \mathrm{~mm}$ diameter plastic Petri dishes were used. After the cells reached the late logarithmic phase of growth, the growth media were replaced with fresh media containing FCS that was pretreated with resin (Samuels et al. 1979) to remove endogenous thyroid hormones. Exchange of the hormone-free media was performed at $48 \mathrm{~h}$ with a single exchange at $24 \mathrm{~h}$ before the experiment. Thirty minutes before the experiment, cells on Petri dishes were washed twice with Hanks' Balanced Salt Solution (HBSS) in order to remove FCS. Uptake studies were performed at $37^{\circ} \mathrm{C}$ in $60 \mathrm{~mm}$ diameter plastic Petri dishes with $2 \mathrm{ml}$ HBSS without serum. $\left[{ }^{125} \mathrm{I}^{\mathrm{T}} \mathrm{T}_{3}(14 \cdot 4 \mathrm{pM})\right.$ with or without unlabeled thyronines was used. After the incubation, cells were immediately cooled on ice and washed twice with ice-cold HBSS. Subsequent procedures were performed at $0-4{ }^{\circ} \mathrm{C}$. After the HBSS was aspirated, cells were lysed by a 10-min incubation with $2 \mathrm{ml} 0 \cdot 25 \mathrm{M}$ sucrose, $1 \mathrm{mM}$ $\mathrm{MgCl}_{2}$ and $20 \mathrm{mM}$ Tris-HCl, $\mathrm{pH} 7 \cdot 4$ (SMT solution) containing $0.5 \%$ Triton X-100. Cell lysate from one dish 


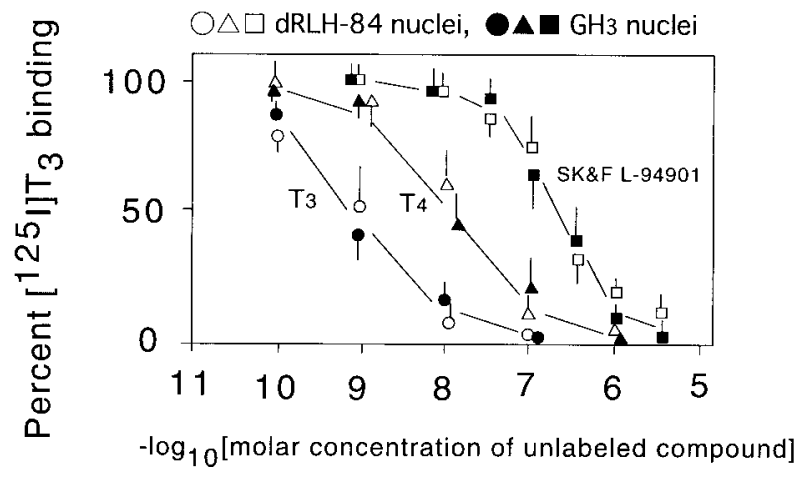

Figure 1 Relative binding potency of various thyronine analogs to isolated nuclei from cultured rat hepatoma ( $\mathrm{dRLH}-84)$ and pituitary tumor $(\mathrm{GH} 3)$ cells. Binding of $\left[{ }^{125} \mathrm{I}\right] \mathrm{T}_{3}$ to $\mathrm{dRLH}-84$ cell nuclei or $\mathrm{GH} 3$ cell nuclei was determined in the presence of various concentrations of iodothyronine analogs $\left(\mathrm{T}_{3}, \mathrm{~T}_{4}\right.$ and SK\&F L-94901). Data are means \pm S.D. of three determinations from one experiment; similar results were obtained in a second experiment.

was divided into two $0.8 \mathrm{ml}$ aliquots in glass tubes. The radioactivity of one aliquot was measured for the determination of whole-cell thyroid hormone uptake. The other aliquot was centrifuged at $1500 \times \mathbf{g}$ for $10 \mathrm{~min}$ at $4{ }^{\circ} \mathrm{C}$. The resultant nuclear pellet was washed twice with SMT and the radioactivity of the nuclear pellet measured for determination of nuclear thyroid hormone uptake. After the determination of the radioactivity in the nuclear pellet, sucrose was removed by two washes with ice-cold PBS, followed by two washes with ice-cold $0.4 \mathrm{M}$ perchloric acid to determine the DNA content of the nuclear pellet in every tube (Burton 1956).

\section{Results}

\section{SKEF L-94901 does not discriminate different TR subtypes}

SK\&F L-94901 inhibited $\left[{ }^{125} \mathrm{I}\right] \mathrm{T}_{3}$ binding to isolated nuclei almost equally in GH3 cells and in dRLH-84 cells (Fig. 1), suggesting that this compound did not discriminate differences in TRs between these different cell types. Time courses of $\left[{ }^{125} \mathrm{I}\right] \mathrm{T}_{3}$ binding to isolated nuclei in the absence or presence of SK\&F L-94901 were indistinguishable between these two cell lines (data not shown). Using soluble TR $\alpha 1$ and $\beta 1$ expressed in insect cells, we tested whether SK\&F L-94901 discriminates these different TR subtypes. The results indicate that the binding affinity for SK\&F L-94901 was almost identical between TR $\alpha 1$ and $\beta 1$ (Fig. 2). In addition, when COS1 cells were cotransfected with plasmid expressing luciferase under the control of TRE (PAL-TK-luciferase) and with plasmid expressing either TR $\alpha 1$ or $\beta 1$, SK\&F L-94901 activated luciferase activity almost equally in both types of receptor (Fig. 3). As the experiments were carried out in media with FCS, which contains thyronine binding proteins,

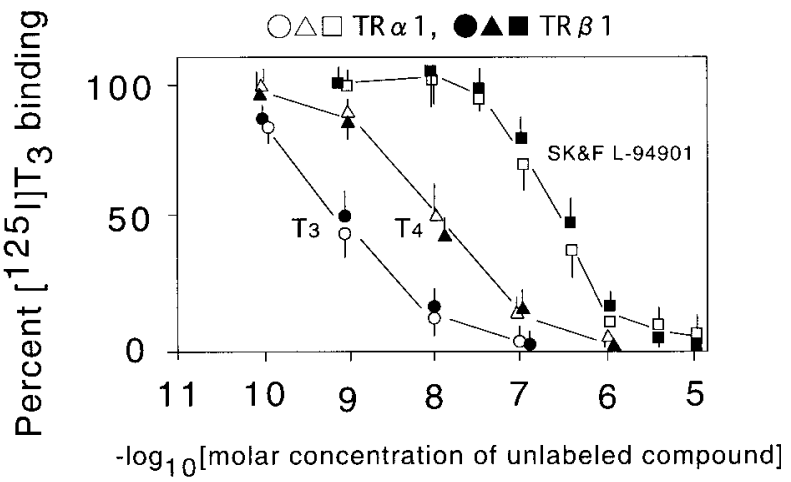

Figure 2 Relative binding potency of various thyronine analogs to TRs $\alpha 1$ and $\beta 1$. Binding of $\left[{ }^{125} \mathrm{I}\right] \mathrm{T}_{3}$ to TR $\alpha 1$ or $\beta 1$ was determined in the presence of various concentrations of iodothyronine analogs $\left(T_{3}, T_{4}\right.$ and SK\&F L-94901). Data are means \pm S.D. of three determinations from one experiment; similar results were obtained in a second experiment.

concentrations of thyronine analogs required for the activation of TRs were greater than those required for binding to TR in cultured cells (Figs 4-6) that were examined in the serum-free media. Neither COS1 cells transfected with PAL-TK-luciferase and pCDM without TR nor those with pCDM expressing TRs and TK-luciferase

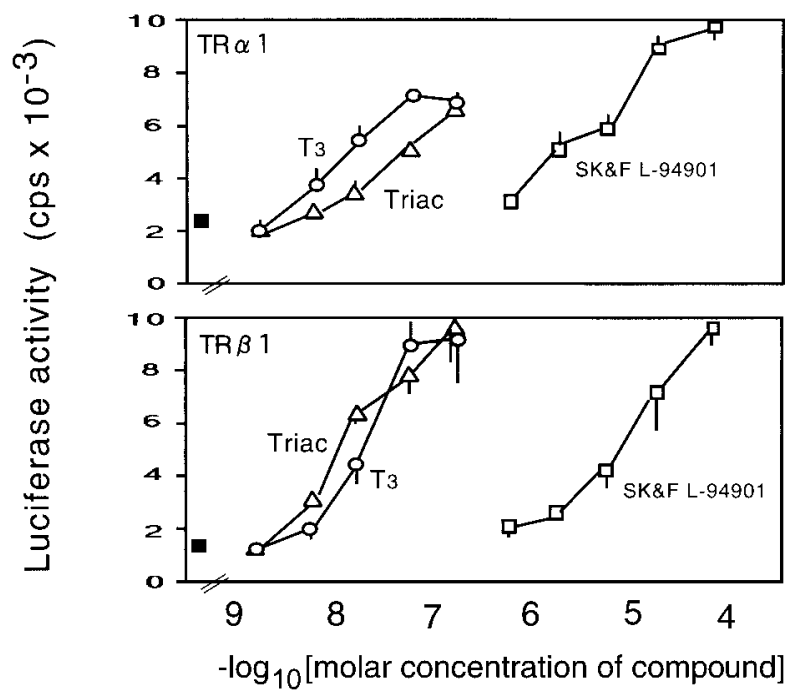

Figure 3 Effect of thyronine analogs on PAL-TK-luciferase activity in COS1 cells co-expressing TR $\alpha 1$ or TR $\beta 1$. COS1 cells cotransfected with plasmids containing PAL-TK-luciferase and plasmids expressing TR $\alpha 1$ (upper panel) or TR $\beta 1$ (lower panel) were incubated for $24 \mathrm{~h}$ in culture media containing $10 \%$ FCS with various concentrations of $\mathrm{T}_{3}, 3,5,3$ '-tri-iodo-L-thyroacetic acid (Triac) or SK\&F L-94901 and luciferase activity was measured. The abscissa indicates the concentration of the thyronine analogs added to the media containing 10\% FCS. $\mathbf{\square}$, Luciferase activity without thyronine analogs. Data are means \pm ranges of duplicate determinations from one experiment; similar results were obtained from a second experiment. 


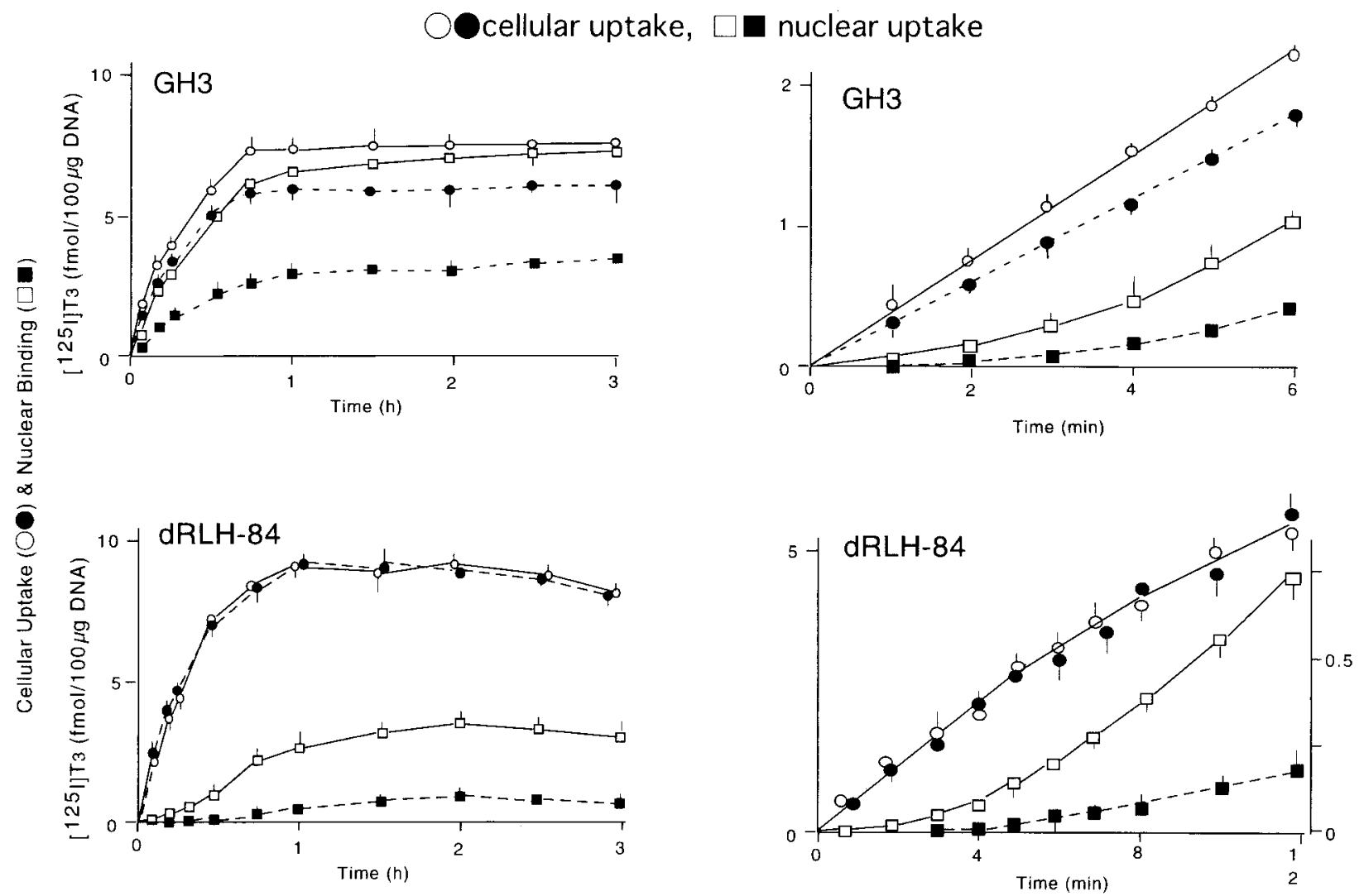

Figure 4 Time course of uptake of $\left[{ }^{125} \mathrm{I}\right] \mathrm{T}_{3}$ by rat pituitary $(\mathrm{GH} 3$; upper panels) and hepatic (dRLH-84; lower panels) cells and nuclei. $0, \square$, Uptake values in the absence of SK\&F L-94901;, $\mathbf{\square}$, values in the presence of $10^{-7} \mathrm{M}(\mathrm{GH} 3 \mathrm{cells})$ or $10^{-8} \mathrm{M}(\mathrm{dRLH}-84 \mathrm{cells})$ SK\&F L-94901. Means \pm ranges of duplicate determinations from one experiment are shown; similar results were obtained from a second experiment.

without PAL (the palindromic TRE) responded to thyroid hormones (data not shown).

Kinetic analysis of cellular uptake of $T_{3}$

The time course of cellular and nuclear uptake of $\left[{ }^{125} \mathrm{I}\right] \mathrm{T}_{3}$ by intact cells was examined using cultured rat hepatoma cells (dRLH-84) and cultured rat pituitary tumor cells (GH3) in the absence or presence of SK\&F L-94901 (Fig. 4). Concentrations of $10^{-7} \mathrm{M}$ and $10^{-8} \mathrm{M}$ SK\&F L-94901 were used for GH3 and dRLH-84 cells respectively. Cellular uptake of $\mathrm{T}_{3}$ over time was linear up to $5 \mathrm{~min}$ in both cells. We used the terms 'initial uptake' for 3 min incubation, 'early uptake' for $10 \mathrm{~min}$ incubation and 'binding equilibrium' for $120 \mathrm{~min}$ incubation. In GH3 cells, $10^{-7}$ M SK\&F L-94901 inhibited cellular uptake of $\mathrm{T}_{3}$ slightly and nuclear uptake of $\mathrm{T}_{3}$ to about $40 \%$. In contrast, in dRLH-84 cells $10^{-8} \mathrm{M}$ SK\&F L-94901 reduced nuclear $\mathrm{T}_{3}$ uptake to $25-30 \%$ without affecting cellular $\mathrm{T}_{3}$ uptake. These effects were seen consistently at every time point. The initial velocity $\left(V_{\mathrm{o}}\right)$ of cellular uptake of $\mathrm{T}_{3}$ was saturable. The double-reciprocal plot of $V_{\mathrm{o}}$ for cellular uptake of $\mathrm{T}_{3}$ against $\mathrm{T}_{3}$ concentration (Lineweaver-Burke plot) was linear at $\mathrm{T}_{3}$ concentrations of $10^{-9}-2 \times 10^{-8} \mathrm{M}$ (low $K_{\mathrm{m}}$ system) and $10^{-7}$ $2 \times 10^{-6} \mathrm{M}$ (high $K_{\mathrm{m}}$ system). The Michaelis constant $\left(K_{\mathrm{m}}\right)$ and maximal velocity $\left(V_{\max }\right)$ values are given in Table 1. Cellular uptake of $\mathrm{T}_{3}$ at low $\mathrm{T}_{3}$ concentrations was inhibited competitively by high concentrations of SK\&F L-9490,1 with $K_{\mathrm{i}}$ values of $130 \mathrm{nM}$ and $1800 \mathrm{nM}$ in GH3 and dRLH-84 cells respectively.

SKEF L-94901 inhibits hepatic nuclear uptake of $T_{3}$ more efficiently than pituitary nuclear uptake of $T_{3}$ in intact cells

In order to compare the nuclear access of SK\&F L-94901 in pituitary (GH3) cells and hepatic (dRLH-84) cells, the potency of SK\&F L-94901 to inhibit early nuclear uptake of $\left[{ }^{125} \mathrm{I}\right] \mathrm{T}_{3}$ was examined using intact cells. Whereas approximately $73 \mathrm{nM}$ SK\&F L-94901 was required for half-maximal inhibition of GH3 nuclear uptake of $\left[{ }^{125} \mathrm{I}\right] \mathrm{T}_{3}$, as little as about $2 \cdot 4 \mathrm{nM}$ was sufficient to exert 


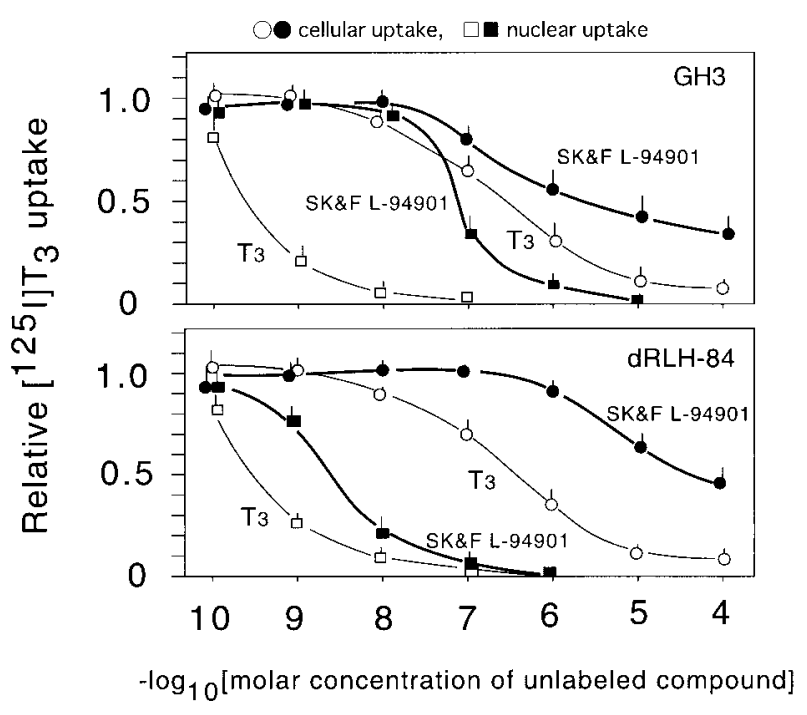

Figure 5 Effect of unlabeled $\mathrm{T}_{3}$ or SK\&F L-94901 on initial uptake of $\left[{ }^{125} \mathrm{I}\right] \mathrm{T}_{3}$ in rat cultured pituitary and hepatic cells. Initial uptake of $\left[{ }^{125} \mathrm{I}_{3}\right.$ to cultured rat pituitary tumor $(\mathrm{GH} 3$; upper panel) and hepatoma (dRLH-84; lower panel) cells and to the respective cell nuclei was determined in the presence of various concentrations of $\mathrm{T}_{3}$ or SK\&F L-94901. Each value was divided by that obtained without unlabeled analogs and expressed on the ordinate. Data are means \pm S.D. of three separate experiments, each performed using duplicate dishes.

half-maximal inhibition of dRLH-84 cell nuclear uptake of $\left[{ }^{125} \mathrm{I}\right] \mathrm{T}_{3}$ (Fig. 5). These data indicate that SK\&F L-94901 enters hepatic cell nuclei more efficiently than pituitary cell nuclei when intact cells are used. However when cellular entry was compared in these cells, the potency of SK\&F L-94901 to inhibit cellular entry of $\left[{ }^{125} \mathrm{I}_{\mathrm{T}} \mathrm{T}_{3}\right.$ was more potent in GH3 cells than in dRLH-84 cells. As a result of the preferential entry of SK\&F L-94901 to hepatic nuclei in intact cells, the inhibition by SK\&F L-94901 of hepatic nuclear $\left[{ }^{125} \mathrm{I}\right] \mathrm{T}_{3}$ binding was stronger at binding equilibrium compared with that of pituitary cell nuclear binding when intact cells were incubated with ligand for $2 \mathrm{~h}$ (Fig. 6). The results are compatible with the idea that nuclear exit of SK\&F L-94901 does not contribute to liver-selective activity and that the liverselective thyromimetic activity of SK\&F L-94901 is due to preferential nuclear access.

We also analysed the ratios of nuclear to medium concentrations of SK\&F L-94901 in these cells. The concentration of SK\&F L-94901 required to inhibit nuclear $\left[{ }^{125} \mathrm{I}\right] \mathrm{T}_{3}$ binding was about 480 - and 23 -fold greater thanthe $\mathrm{ID}_{50}$ of $\mathrm{T}_{3}$ in whole-cell incubations of GH3 and dRLH-84 cells respectively (Fig. 6), compared with 264- and 380-fold values in the case of isolated nuclei (Fig. 1). Taking into account that $\mathrm{T}_{3}$ is actively transported from medium to nucleus and that the free $T_{3}$ concentration is $5-10$-fold greater in the nucleus than in media (Freake et al. 1986), nuclear free SK\&F L-94901 concen-

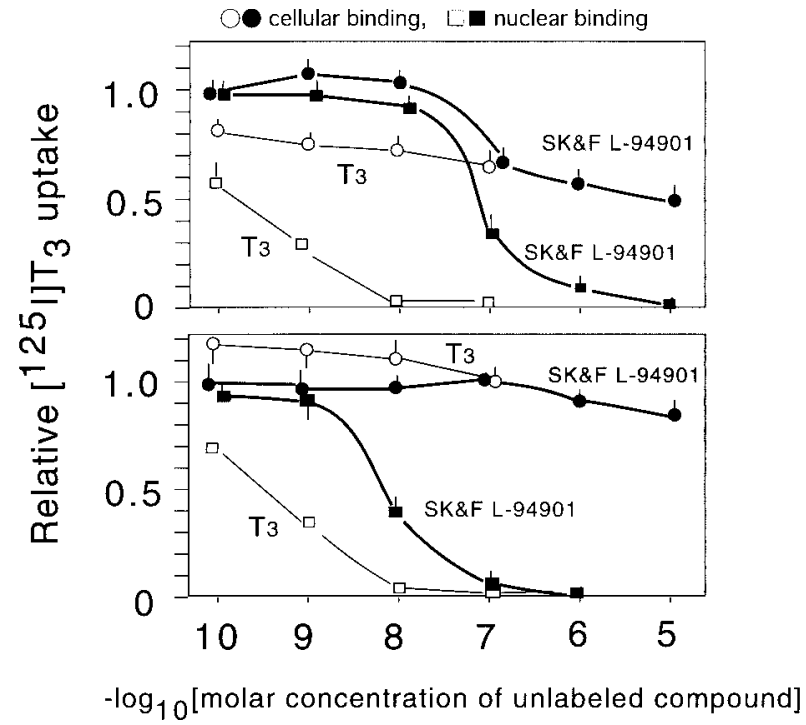

Figure 6 Effect of unlabeled T $T_{3}$ or SK\&F L-94901 on cellular and nuclear $\left[{ }^{125} \mathrm{I}\right] \mathrm{T}_{3}$ after binding equilibrium. Cultured rat pituitary tumor (GH3; upper panel) and hepatoma (dRLH-84; lower panel) cells were incubated with $\left[{ }^{125} \mathrm{IIT}_{3}\right.$ and various concentrations of $\mathrm{T}_{3}$ or SK\&F L-94901. After $2 \mathrm{~h}$ of incubation, cellular [ $\left.{ }^{125} \mathrm{I}\right] \mathrm{T}_{3}$ and nuclear $\left[{ }^{125} \mathrm{I}\right] \mathrm{T}_{3}$ were determined. Each value was divided by that obtained without unlabeled analogs and expressed on the ordinate. Data are means \pm S.D. of three separate experiments, each performed using duplicate dishes.

trations were $2 \cdot 8-5 \cdot 5$ and $80-170$ times greater than the free SK\&F L-94901 concentrations in the media in GH3 and dRLH-84 cells respectively.

\section{Discussion}

In the present study, we studied the mechanisms by which SK\&F L-94901 shows liver-selective thyromimetic activity. As the TRs exist in multiple forms such as $\alpha 1, \beta 1$ and $\beta 2$ and various organs contain them in different ratios (Schwartz et al. 1992), we tested whether SK\&F L-94901 specifically recognizes the hepatic receptor or not. Our results showed that SK\&F L-94901 bound equally to both hepatic and pituitary receptors in isolated nuclei. In

Table 1 Kinetics of cellular uptake of $\mathrm{T}_{3} . K_{\mathrm{m}}$ and $V_{\max }$ were calculated from double-reciprocal plots of $\mathrm{T}_{3}$ concentration against initial (3-min) $\mathrm{T}_{3}$ uptake by GH3 and dRLH-84 cells

\begin{tabular}{|c|c|c|}
\hline & GH3 cells & dRLH-84 cells \\
\hline $\begin{array}{l}\text { Low } K_{\mathrm{m}} \text { system } \\
\qquad K_{\mathrm{m}}(\mathrm{nmol} / \mathrm{l}) \\
V_{\max }(\mathrm{fmol} / 10 \mu \mathrm{g} \mathrm{DNA} / \mathrm{min})\end{array}$ & $\begin{array}{l}18 \\
90\end{array}$ & $\begin{array}{r}11 \\
180\end{array}$ \\
\hline $\begin{array}{l}\text { High } K_{\mathrm{m}} \text { system } \\
K_{\mathrm{m}}(\mathrm{nmol} / \mathrm{l}) \\
V_{\max }(\mathrm{fmol} / 10 \mu \mathrm{gNA} / \mathrm{min})\end{array}$ & $\begin{array}{r}600 \\
2600\end{array}$ & $\begin{array}{l}1000 \\
3900\end{array}$ \\
\hline
\end{tabular}


addition, it bound and activated TRs $\alpha 1$ and $\beta 1$ almost equally. We therefore considered that the liver selectivity of SK\&F L-94901 was not exerted at the receptor level. Instead, whole-cell incubation studies revealed that binding of SK\&F L-94901 to the nuclear TR was significantly stronger in hepatic cells than in pituitary cells and that the binding of SK\&F L-94901 to the receptor in whole cells was stronger than that in isolated nuclei in both cell lines. These findings were consistently observed throughout the time-course of the experiment from the initial phase of the uptake process to binding equilibrium. These data indicate that nuclear transport of SK\&F L-94901 is active and that the nuclear concentration of SK\&F L-94901 is greater than the extracellular concentration at binding equilibrium in both cell lines. SK\&F L-94901 is more actively transported to the nucleus and shows greater occupancy of the nuclear receptors in hepatic cells than in pituitary cells, therefore achieving liver-selective thyromimetic action. Other rat hepatoma cells (Hepa 1) and cultured human hepatoblastoma cells (Hep G2) gave results similar to those obtained with dRLH-84 cells, whereas cultured human fibroblasts showed results similar to those with GH3 cells (data not shown).

As our data concerned the inhibition of $\left[{ }^{125} \mathrm{I}\right] \mathrm{T}_{3}$ binding by unlabeled SK\&F L-94901, we do not know the cytoplasmic concentrations of SK\&F L-94901. The less potent inhibition of dRLH-84 cellular uptake of $\left[{ }^{125} \mathrm{I}\right] \mathrm{T}_{3}$ by SK\&F L-94901 is relevant only to the uptake procesess common to $\mathrm{T}_{3}$ and $\mathrm{SK} \& \mathrm{~F} \mathrm{~L}-94901$. If there are alternative cellular processes of SK\&F L-94901 uptake that are not shared by $\mathrm{T}_{3}$, we would not be able to detect them unless we use radiolabeled SK\&F L-94901. However, our assay gives correct information on the binding of SK\&F L-94901 to nuclear TR, as more than $98 \%$ of nuclear $\left[{ }^{125} \mathrm{I}\right] \mathrm{T}_{3}$ was bound to nuclear $\mathrm{TR}$, as verified by the binding specificities and relative binding affinities to various thyronines. We are therefore able to conclude that hepatic nuclei take up and concentrate more SK\&F L-94901 than do pituitary nuclei, as a result either of enhanced cellular uptake or of enhanced transfer from cytoplasm to nucleus. It is also possible that instead of favoring the nuclear uptake of SK\&F L-94901 in the liver, mechanisms may exist that impair the nuclear uptake of SK\&F L-94901 in the pituitary.

What makes SK\&F L-94901 preferentially enter hepatic nuclei in intact cells? We showed previously that rat hepatic cytosol contains thyroid hormone binding protein (cTBP) (Hashizume et al. 1991, Nishii et al. 1993, Takeda et al. 1994), the thyroid hormone binding of which is markedly stimulated by NADPH or NADP and DTT. Subsequent studies revealed that NADPH-activated cTBP inhibits but NADP-DTT-activated cTBP promotes thyroid hormone uptake to nuclei. cTBP was abundant in cultured rat hepatoma cells (dRLH-84) (Hashizume et al. 1991) but was absent from cultured rat pituitary tumor cells (GH3)(data not shown). We therefore considered the possibility that SK\&F L-94901 might bind more potently to NADP-DTT-activated cTBP than to NADPHactivated CTBP, thus allowing more preferential nuclear transition in hepatic cells. However, binding of SK\&F L-94901 to these different types of cTBP was almost equal (data not shown), eliminating such a possibility.

To date, we remain unaware of the mechanisms by which SK\&F L-94901 discriminates hepatic nuclear transport and pituitary nuclear transport. It is possible that nuclear transport carriers are different in these different cell types. Isolation of the cellular thyroid hormone transporter is now in progress.

\section{Acknowledgements}

We are grateful to Kissei Pharmaceutical Co. (Matsumoto, Japan) for providing us with SK\&F L-94901.

\section{References}

Baniahmad A, Ha I, Reinberg D, Tsai S, Tsai M-J \& O’Malley BW 1993 Interaction of human thyroid hormone receptor beta with transcription factor TFIIB may mediate target gene derepression and activation by thyroid hormone. Proceedings of the National Academy of Sciences of the USA $908832-8836$.

Burton K 1956 Study of the conditions and mechanism of the diphenylamine reaction for the calorimetric estimation of deoxyribonucleic acid. Biochemical Journal 62 315-323.

Eckel J, Rao GS, Rao ML \& Breuer H 1979 Uptake of L-triiodothyronine by isolated rat liver cells. Biochemical Journal 182 473-491.

Everts ME, De Jong M, Lim C-F, Docter R, Krenning EP, Visser TJ \& Hennemann G 1996 Different regulation of thyroid hormone transport in liver and pituitary: its possible role in the maintenance of low T3 production during nonthyroidal illness and fasting in man. Thyroid 6 359-368.

Freake HC, Mooradian AD, Schwartz HL \& Oppenheimer JH 1986 Stereospecific transport of triiodothyronine to cytoplasm and nucleus in GH1 cells. Molecular and Cellular Endocrinology 44 25-35.

Hashizume K, Suzuki S, Ichikawa K, Takeda T \& Kobayashi M 1991 Effect of active vitamin D3 on the level of NADPH-dependent cytosolic 3,5,3'-triiodo-L-thyronine-binding protein. Biochemical and Biophysical Research Communications 177 388-394.

Ichikawa K, DeGroot LJ, Refetoff S, Horwitz AL \& Pollak ER 1986 Nuclear thyroid hormone receptors in cultured human fibroblast: improved method of isolation, partial characterization, and interaction with chromatin. Metabolism 35 861-868.

Ichikawa K, Hashizume K, Kobayashi M, Nishii Y, Ohtsuka H, Suzuki S, Takeda T \& Yamada T 1992 Heat shock decreases nuclear transport of $3,5,3^{\prime}$-triiodo-L-thyronine in clone 9 cells. Endocrinology 130 2317-2324.

Krenning EP, Docter R, Bernard HF, Visser TJ \& Hennemann G 1989 Active transport of triiodothyronine (T3) into isolated rat liver cells. FEBS Letters 91 113-116.

Lazar MA 1993 Thyroid hormone receptors: multiple forms, multiple possibilities. Endocrine Reviews 14 184-193.

Lee JW, Choi H-S, Gyuris J, Brent R \& Moore DD 1995 Two classes of proteins dependent on either the presence or absence of thyroid hormone for interaction with the thyroid hormone receptor. Molecular Endocrinology 9 234-254.

Lein A \& Dowben RM 1961 Uptake and binding of thyroxine and triiodothyronine by rat diaphragm in vitro. American Journal of Physiology 200 1029-1032. 
Lopez G, Schaufele F, Webb P, Holloway J, Baxter J \& Kushner PJ 1993 Positive and negative modulation of Jun action by thyroid hormone receptor at a unique AP-1 site. Molecular and Cellular Biology 13 3042-3049.

Miyamoto T, Suzuki S \& DeGroot LJ 1993 High affinity and specificity of dimeric binding of thyroid hormone receptors to DNA and their ligand-dependent dissociation. Molecular Endocrinology 7 224-231.

Miyamoto T, Kaneko A, Kamijo K, Sekine R, Kakizawa T, Yajima H, Hiramatsu K, Nishii Y, Hashimoto T \& Hashizume K 1997 Inhibition of peroxisomal proliferator signalling pathways by thyroid hormone receptor. Journal of Biological Chemistry 272 $7752-7758$

Nagasawa T, Ichikawa K, Minemura K, Hara M, Yajima H, Sakurai A, Kobayashi H, Hiramatsu K, Shigematsu S \& Hashizume K 1995 Differences in cellular transport of triiodothyronine and thyroxine: cell cycle-dependent alteration of triiodothyronine uptake. Journal of Endocrinology 147 479-485.

Nakai A, Sakurai A, Bell GI \& DeGroot LJ 1988 Characterization of a third human thyroid hormone receptor coexpressed with other thyroid hormone receptors in several tissues. Molecular Endocrinology 2 1087-1092.

Nishii Y, Hashizume K, Ichikawa K, Takeda T, Kobayashi M, Nagasawa T, Katai M, Kobayashi H \& Sakurai A 1993 Induction of cytosolic triiodo-L-thyronine (T3) binding protein by T3 in primary cultured rat hepatocytes. Endocrinologica Japonica 40 399-404.

Oppenheimer JH \& Schwartz HL 1985 Stereospecific transport of triiodothyronine from plasma to cytosol and from cytosol to nucleus in rat liver, kidney, brain, and heart. Journal of Clinical Investigation 75 147-154.

Oppenheimer JH, Schwartz HL, Mariash CN, Kinlaw WB, Wong NCW \& Freake HC 1987 Advances in our understanding of thyroid hormone action at the cellular level. Endocrine Reviews $\mathbf{8}$ 288-308.
Samuels HH, Stanley F \& Casanova J 1979 Depletion of L-3,5,3'triiodothyronine and L-thyroxine in euthyroid calf serum for use in cell culture studies of the action of thyroid hormone. Endocrinology $10580-85$.

Schwartz HL, Strait KA, Ling NC \& Oppenheimer JH 1992 Quantitation of rat tissue thyroid hormone binding receptor isoforms by immunoprecipitation of nuclear triiodothyronine binding capacity. Journal of Biological Chemistry 267 11794-11799.

Summers MD \& Smith GE 1988 A manual of methods for baculovirus vectors and insect cell culture procedures. Texas Agricultural Experiment Station, Bulletin 1555. Texas: The Texas A \& M University System.

Takeda T, Ichikawa K, Kobayashi M, Miyamoto T, Suzuki S, Nishii Y, Sakurai A, Nagasawa T, Katai M, Nakajima K \& Hashizume K 1994 Response of hepatic proteins to 3,5,3'-tri-iodo-L-thyronine in diabetic rats. Journal of Endocrinology 143 55-63.

Tanaka M, Noguchi T, Inoue H, Yamada K, Matsuda T \& Tanaka T 1989 Rat pyruvate kinase M gene. Journal of Biological Chemistry $2642363-2367$.

Tashjian AH Jr, Yasumura Y, Levine L, Sato GH \& Parker ML 1968 Establishment of clonal strains of rat pituitary tumor cells that secrete growth hormone. Endocrinology 82 342-352.

Underwood AH, Emmet JC, Ellis D, Flynn SB, Leeson PD, Benson GM, Novelli R, Pearce NJ \& Shah VP 1986 A thyromimetic that decreases plasma cholesterol levels without increasing cardiac activity. Nature 324 425-429.

Weisiger RA, Luxon BA \& Cavalieri RR 1992 Hepatic uptake of 3,5,3'-triiodothyronine: electrochemical driving forces. American Journal of Physiology 262 G1104-G1112.

Received 19 April 1999

Revised manuscript received 20 September 1999 Accepted 11 January 2000 